\title{
Incorporating Agroecology Into Organic Research -An Ongoing Challenge
}

\author{
Urs Niggli ${ }^{1}$ \\ ${ }^{1}$ Research Institute of Organic Agriculture (FiBL), Switzerland \\ Correspondence: Urs Niggli, Research Institute of Organic Agriculture (FiBL), CH-5070 Frick, Switzerland. Tel: \\ 41-628-657-270. E-mail: urs.niggli@fibl.org
}

Received: March 19, 2015 Accepted: July 8, 2015 Online Published: July 13, 2015

doi:10.5539/sar.v4n3p149 URL: http://dx.doi.org/10.5539/sar.v4n3p149

\begin{abstract}
Agroecology - as a scientific discipline and as an approach to sustainable farming practice - has objectives similar to those of organic agriculture. The paper sharpens the profile of both concepts and identifies strengths and weaknesses. The overarching challenge of both is to minimize trade-offs between food and fiber production on the one hand and non-commodity ecosystem services on the other hand. A comparison of the two approaches may well be inspiring, especially for the future development of organic food systems.

Best use of human, social and natural capital characterizes organic farmers, especially in developing countries, as documented by many case studies from sub-Saharan Africa. That also applies to organic farms in temperate zones, although usually more external inputs are used in organic farming there. While the profitability of organic farms is comparable to or slightly higher than that of conventional ones, per area food production is lower by an average of 20 to 25 percent in temperate zones. Overly restrictive production standards are often mentioned as the cause, but also a lag in production techniques. One of the main approaches of organic agriculture to augment productivity is ecological or eco-functional intensification. Thereby, the goal is to maintain the ecological and social qualities of the farms and to increase food output. The future development of organic agriculture can be characterized by a comprehensive culture of innovation embracing social, ecological and technological innovations. Such a concept of innovation includes dynamic interactions between farmers and scientists in order to strengthen system resilience and make better use of basic research from a wide range of scientific disciplines.
\end{abstract}

Keywords: agroecology, organic agriculture, eco-functional intensification, innovation

\section{Introduction}

The former UN Special Rapporteur on the Right to Food, Olivier De Schutter, made strong recommendations in his final report in favor of agroecology (De Schutter, 2014). Productivity could be doubled in regions where the hungry live if agroecological methods are adopted. De Schutter saw agroecological science and practice as the most favorable way to boost future food production. Although he identified similarities between organic agriculture and agroecology, De Schutter did not emphasize organic agriculture in particular. To cope with the grand challenges of humanity ahead, 'we urgently need to adopt the most efficient farming techniques available' he wrote. In this article, the concepts of organic agriculture as part of agroecology and the respective farming practices are discussed. Furthermore, the consequences for future innovation in organic agriculture are deduced.

\section{Organic Agriculture at a Crossroads}

The history of organic agriculture reaches back to the early $20^{\text {th }}$ century. It was one of the very first social movements in agriculture, food and nutrition with strong roots in Europe and the United States of America (Vogt, 2007). Many farmers, scientists and consumers perceived organic farming as a paradigm shift in agriculture (Wynen, 1996; Beus \& Dunlap, 1991). 
Table 1. Description of organic agriculture as a new paradigm (Beus \& Dunlap, 1991)

\begin{tabular}{ll}
\hline Conventional farming & Organic farming \\
\hline Dependence & Independence \\
Competition & Community \\
Domination of nature & Harmony with nature \\
Specialization & Diversity \\
Exploitation & Restraint \\
\hline
\end{tabular}

A paradigm shift in society finally leads to the adoption of new ideas by the respective mainstream activity or context (Kuhn, 1970). This has occurred in the case of agriculture as well; a multitude of "sustainable" farming systems have emerged in the last 30 years, at least partly inspired by organic agriculture. These include conservation tillage, integrated pest management, integrated production, precision farming, low input agriculture, low external input, sustainable agriculture, agroecological farming, permaculture and agroforestry systems. On the other hand, organic agriculture has developed into a highly standardized food production protocol regulated by 80 national laws (Huber et al., 2015). As a consequence of the growth in organic food trade, bilateral negotiations on equivalence or even compliance have become an important aspect of the sector (Huber et al., 2015; ITF, 2008). Eighty percent of organic food is consumed in the US and EU markets, while seventy-five percent of the producers produce outside of these two major domestic markets (Willer \& Lernoud, 2015). In most European countries, conversion rates of farmers to organic agriculture are low although market demand is huge and direct payment schemes support conversion (Willer \& Lernoud, 2015). In export-oriented countries, the growing trade threatens the regionalization and contextualization of organic agriculture because the standards of the EU and US markets are the dominant requirements (Oelofse, 2010). It was mainly the strenuous work of organic pioneer organizations in the 1970s to agree on the global standard of the International Federation of Organic Agriculture Movements (IFOAM) which enabled a prosperous global trade in organic commodities 30 years later (Geier, 2007; Schmid, 2007).

Two opposing developments can currently be identified: Conventional agriculture is adopting ecological and social elements of sustainability while organic agriculture is becoming globally standardized, potentially losing part of its diversity and becoming more business oriented. Questions thus arise on the positioning and unique profile of organic agriculture compared to the fast growing number of currently 435 labels with sustainability claims (COSA, 2013) such as Rainforest Alliance, UTZ, Fair Trade and others. Most of them apply one or several farm practices typical of agroecology (see the listing of agroecological approaches in Parmentier, 2014 and Wezel et al., 2014).

These discussions are especially intense in Europe, where support for organic agriculture is part of the political schemes for rural development and part of the agri-environment regulation EU 2078/92 (Council of the European Communities, 1992), which seeks to raise awareness among farmers of environment-friendly farm practices. Ensuring best farm practice and a high level of ecological, social and economic sustainability is an important issue in this context - equally important as meeting the quality expectations of consumers. Such concepts of best practice are part of the discussion under the slogan "Organic 3.0". The term was first introduced by Braun et al. in 2010. In 2014, it was launched as an international campaign by IFOAM (Arbenz, 2015; Rützler and Reiter, 2014).

\section{The Development of Agroecology}

Agroecology as introduced by Altieri (1995) was a scientific discipline concerned with the application of ecology to agricultural systems. Since then, it has become the overarching concept of a growing number of agricultural universities and state research institutes. The German Research Fund, which finances fundamental science across all disciplines, qualified agricultural research as a system approach (DFG memorandum, 2005): Due to the paradigm shift in society, agricultural research addresses "interdependencies with environmental and social sciences, and ecology gains in importance as a source of relevant theories" the DFG memorandum wrote.

In Latin America, smallholder farmers have increasingly taken up the findings of agroecological research and have developed farm practice accordingly (Altieri et al., 2015; Altieri \& Nicholls, 2005). The goal is to optimize productivity with best use of natural capital and to reduce dependence on costly inputs such as fertilizers and pesticides. Such practices encompass local breeding programs aiming at improving the quality and yield of locally adapted species and cultivars (Koohafkan et al., 2011). These programs take up the experience of farmers, 
especially women who are often responsible for the maintenance of seeds and tubers.

Most recently, the government of France has defined agroecology as the general principle of agricultural practice with consequences for the orientation of future research by the French National Institute for Agricultural Research (INRA) with 8500 full-tenure staff members (Ministère de l'algriculture, de l'agroalimentaire et de la forêt, 2013). In Switzerland, all state support schemes have been addressed exclusively to farms which apply several agroecological practices since 2006 (BLW, 2015). With the new Common Agricultural Policy (CAP), the European Commission established in 2014 a policy of 'greening' and required a few agroecological practices for all direct payments. These practices encompass hedgerows and other diverse habitats on five percent of the agricultural land, a more diversified crop rotation and restricted ploughing of permanent grassland (European Commission, 2013).

Finally, agroecology is a social movement and is strongly linked to the food sovereignty movement in Latin America and similar movements across the entire world (Wezel et al., 2009). A politically very active organization is Via Campesina which advocates for small-holder farmers, agroecological farming and food sovereignty (Via Campesina, 2015). In regions where agroecological initiatives and projects have become durable and farmers have not relapsed to unsustainable practices, it was the result of farmers and civil society organisations having become organized as a movement (Tittonell, 2014).

The principles and characteristics of both agroecological research and farm practices (Table 2) are almost identical with those of organic agriculture. Therefore, co-operation between the two concepts is fruitful and should be expanded greatly.

Table 2. Characteristics of agroecology (Altieri et al., 2015, Levidow et al., 2014)

\begin{tabular}{|l|l|}
\hline Agroecological research & Agroecological farm practices (principles) \\
\hline $\begin{array}{l}\text { Develops more autonomous, participatory ways of } \\
\text { producing knowledge that is ecologically literate, } \\
\text { socially just and relevant in the context. }\end{array}$ & $\begin{array}{l}\text { Less dependence on monoculture systems, input } \\
\text { substitution, external input markets and costly } \\
\text { biotechnology packages. }\end{array}$ \\
\hline $\begin{array}{l}\text { More responsibility and decision making power to } \\
\text { farmers and citizens. }\end{array}$ & $\begin{array}{l}\text { Integrated agroecosystems (based on functional } \\
\text { biodiversity and on eco-functional intensification). }\end{array}$ \\
\hline $\begin{array}{l}\text { More significant roles of farmers, food workers, } \\
\text { citizens-consumers in the production and validation } \\
\text { of agroecological knowledge. }\end{array}$ & $\begin{array}{l}\text { Resource availability from local agro-ecosystems } \\
\text { (recycling). }\end{array}$ \\
\hline & Protect environment and produce public goods. \\
\hline & $\begin{array}{l}\text { Local or regional market structures (circular economy } \\
\text { models). }\end{array}$ \\
\hline $\begin{array}{l}\text { Territorial development strategies (also food } \\
\text { sovereignty) and interventions by social movements. }\end{array}$ \\
\hline
\end{tabular}

Agroecological research started from pest prevention, where biodiversity plays an important role (Altieri et al., 2015). Organic research in contrast was first very focused on soil fertility and on the specific methods which were introduced by biodynamic farming (Vogt, 2007). In this day and age, the research agendas for and with organic and agroecological farmers are similarly comprehensive, which delivers synergies for both farming practices (Lutzeyer \& Kovacs, 2012; Stinner, 2007; Niggli, 2007 a; Niggli 2007b; Lange et al., 2006.; Wezel et al., 2009; Wezel et al., 2014).

While the principles of agroecological farming are almost identical to organic principles, the techniques and requirements on farms exhibit relevant differences. Because agroecological farming is not market-driven, clear entry thresholds are absent (Table 3). In contrast, organic farming has clear and rigorous restrictions and bans (e.g., no synthetic pesticides, fertilizers and processing aids and additives, no genetically modified organisms or products thereof) and farms are decertified and lose access to markets when they violate the restrictions (Table 3). Certification is an integral part of the requirements for an organic farm and is prominently regulated by both state systems and private labels. There is a certain flexibility in the choice of certification methods: Third-party audits according to ISO standards are most commonly used. For groups of smallholder producers, group certification is also applied, again supervised by a third-party audit. Some countries like Brazil allow 
Participatory Guarantee Systems (PGS) where the proximity of farmers, consumers and trade replace an external control (Table 3).

Agroecological farms on the other hand are more flexible in many ways. Some of their techniques are not compatible with organic standards, like combined fertilization with organic manure and mineral fertilizers (including nitrate) or the spraying of herbicides and pesticides in order to prevent yield losses (Parmentier, 2014).

Table 3. Practices and techniques of organic and agroecological farms

\begin{tabular}{|c|c|c|}
\hline Level & Agroecological farms & Organic farms \\
\hline Principles & $\begin{array}{l}\text { Many excellent principles and } \\
\text { recommendations, comparable to organic } \\
\text { farming; not codified (Altieri et al, } \\
\text { 2015). }\end{array}$ & $\begin{array}{l}\text { The four principles of health, ecology, fairness } \\
\text { and care, worded in the same spirit as } \\
\text { agroecology but codified (national and } \\
\text { international law) (IFOAM, 2015; Huber et al., } \\
\text { 2015). }\end{array}$ \\
\hline $\begin{array}{l}\text { System redesign } \\
\text { and prevention }\end{array}$ & \multicolumn{2}{|c|}{$\begin{array}{l}\text { On both farm types, preventive techniques prevail which strengthen the farm system and } \\
\text { make it more resilient. They include landscape management, habitat enrichment, crop } \\
\text { rotation, polyculture, catch and cover crops, agroforestry systems and mixed farms } \\
\text { (crop/livestock) (Wezel et al., 2014; Zehnder et al., 2007, Lampkin, 1990). }\end{array}$} \\
\hline Off-farm input & \multicolumn{2}{|c|}{$\begin{array}{l}\text { Reduction of off-farm inputs by prevention, nutrient cycling, biological } \mathrm{N} \text { fixation, natural } \\
\text { regulation of pests and natural amendments and biological pest control is paramount for } \\
\text { both organic and agroecological farm practice (Wezel et al, 2014; Lampkin, 1990). }\end{array}$} \\
\hline $\begin{array}{l}\text { Input regulation } \\
\text { and GMOs }\end{array}$ & $\begin{array}{l}\text { No general bans on inputs. No positive } \\
\text { lists of accepted inputs. } \\
\text { Agroecology does not exclude synthetic } \\
\text { and chemical pesticides and fertilizers on } \\
\text { "ideological grounds" (Parmentier, } \\
\text { 2014). If a technology improves } \\
\text { productivity for farmers and does not } \\
\text { cause undue harm to the environment, it } \\
\text { can be applied (Wezel et al., 2014; } \\
\text { Parmentier, 2014; Pretty, 2008). } \\
\text { GMOs are incompatible with } \\
\text { agroecology as they increase peasants' } \\
\text { dependence on agro-industry, have } \\
\text { harmful impacts on the environment and } \\
\text { biodiversity, reduce soil fertility, increase } \\
\text { economic costs for farmers and increase } \\
\text { criminalization of peasants as a result of } \\
\text { the patents (Parmentier, 2014). }\end{array}$ & $\begin{array}{l}\text { Off-farm inputs are strictly regulated in positive } \\
\text { lists. Everything not listed is banned and leads } \\
\text { to suspension of certification. Inputs accepted } \\
\text { on organic farms are registered according to } \\
\text { clear criteria such as derivatives from natural } \\
\text { compounds and living organisms. A few } \\
\text { traditional chemical inputs like copper } \\
\text { fungicides are used with restrictions. Bans on } \\
\text { synthetic pesticides, mineral fertilizers and } \\
\text { GMOs. } \\
\text { Genetic engineering and many other breeding } \\
\text { techniques are "excluded methods" (NOSB, } \\
\text { 2013). The concept of the integrity of plants } \\
\text { entails the genotypic integrity or the intact } \\
\text { genome (Lammerts van Bueren et al., 2003). As } \\
\text { consequences, cell fusion is forbidden in } \\
\text { organic breeding (yet not for seed propagation) } \\
\text { and substances derived from genetically } \\
\text { engineered bacteria such as synthetic } \\
\text { amino-acids are banned. }\end{array}$ \\
\hline $\begin{array}{l}\text { Standards, } \\
\text { regulation and } \\
\text { certification }\end{array}$ & $\begin{array}{l}\text { No mandatory standards, inspection and } \\
\text { certification. } \\
\text { No standards for food processing, } \\
\text { storage, packaging and trade are in place. }\end{array}$ & $\begin{array}{l}\text { Organic standards are mandatory for farmers } \\
\text { and include processing and distribution. A } \\
\text { third-party audit (pursuant to ISO standards) is } \\
\text { in place and a law is in force in more than } 80 \\
\text { countries. In departure from ISO standards, } \\
\text { group certification is possible in some countries } \\
\text { and the participatory guarantee system (PGS) } \\
\text { under which no independent audits are enforced } \\
\text { is applied for local markets in a few countries } \\
\text { (Huber et al., 2015; Kirchner, 2015). }\end{array}$ \\
\hline Adoption & Farmers often start with using a few & Organic farmers comply with all elements of \\
\hline
\end{tabular}


agroecological practices. Learning from other farmers is important as they become confident with further practices so that they abandon conventional techniques step by step. When farmers begin with agroecological practices, they already have the status agroecology. Convergence with all principles is the final goal. the standards from the $1^{\text {st }}$ day on they convert. Therefore, the entry threshold is high and challenging. Applying only a few organic practices is not an option. As long as full compliance is not achieved, farms remain conventional.

Agroecological practices include already well established farming systems like Low External Input Sustainable Agriculture (LEISA), Organic Farming, Permaculture and (Successional) Agroforestry Systems. Most recently, the concept of agroecology is also being taken over by industrial agriculture by subsuming Low Input Agriculture (LIA), Precision Farming, Integrated Pest Management and Integrated Production as well as Conservation Tillage under agroecological farm practices, a development criticized by smallholder farmers (Via Campesina, 2015).

\section{Discussion of the Consequences for the Future Development of Organic Agriculture}

The comparison of organic agriculture and agroecology, both as a concept for research and for farming practice, is used in the following discussion for reflecting on potential consequences for the future development of organic agriculture. Several concept papers addressing the future of organic agriculture are in statu nascendi and will conceptualize "Organic 3.0". The discussion in this paper reflects the ideas of the author who is involved in the concept papers of IFOAM (not yet published) and the German-speaking organic associations (not yet published).

The need for innovation in organic agriculture is one of the main drivers of the current discussions. Organic farms have become highly differentiated in terms of size, complexity or specialization, labor input, level of intensity, mechanization, profitability and marketing. Consequently, the pathways for innovations are manifold and in parts even contradictory (e.g. between organic pastoralists and organic greenhouse vegetable growers). Although the future innovation strategies are held together by the principles of organic agriculture (IFOAM, 2015), amendments of the standards and regulations may become needed. Unlike organic agriculture, agroecology uses a wider range of technological innovations, especially in developed economies (Table 3). Agroecology also fosters social innovation among smallholder farmers in developing countries.

What could be learnt from agroecological farm practices and how could it be effectuated in the context of organic agriculture? The most important conclusion is that organic agriculture has to implement more rigorously a comprehensive culture of social, ecological and technological innovation.

Firstly, social innovation is a powerful tool and can contribute to local food sovereignty and improved livelihoods in an organic setting. Subsistence farms in sub-Saharan Africa or pastoralists, for example, can considerably improve their crop or meat/milk yields and profitability by using state-of the-art organic techniques (Hine et al., 2008). The better use of human and social capital e.g. by farmer-to-farmer learning or by extension work and on-farm experimenting are the first and important steps to take, reducing not only food insecurity but also dependence on expensive off-farm inputs and therefore also indebtedness (Hine et al., 2008 report case studies of 1.9 million organic and subsistence farmers in sub-Saharan Africa where yields were doubled with good organic practice). While many more independent and non-business facilitators of knowledge on best practices are needed, a better understanding of the factors which restrict the adoption of best practices by farmers or rural societies is also relevant. Socio-economic research can provide these analyses. Social innovations are also supportive of farmer livelihoods in developed economies, especially through farmer-consumer partnerships such as community supported agriculture (CSA), direct marketing with Internet-based media and box schemes (Zahnder \& Hamm, 2009).

Farmer-driven innovation also encompasses technical aspects of farming. Such fields of applied research (or of unraveling existing knowledge) can concern site-specific techniques, knowledge bound to local cultivars, botanicals used in plant protection and veterinary treatments, as well as agroforestry, rainwater harvesting and soil erosion prevention techniques. Interviews with a few hundred organic farmers in Switzerland, for instance, have resulted in well over 1000 prescriptions of botanicals practiced by farmers and verified by pharmaceutical and veterinarian scientists (Disler et al., 2013). The most important aspect of listening to farmers therefore is to systematically extract, evaluate and preserve indigenous or tacit knowledge of farmers and farm communities. 
Secondly, similar to social innovation, ecological innovation is not yet fully exploited. On that point, the concept of "eco-functional intensification" as it was proposed for the EU-Research Framework by the European organic farmers stands for making better use of supporting and regulating services (like soil fertility, carbon sequestration, biodiversity) for higher and more stable yields (Niggli et al., 2008). Part of this innovation concept is to use natural capital better for productivity increases. The concept of eco-functional intensification only works when non-commodity ecosystems services are not lessened nor degraded by the farmers. Such an intensification strategy also strives to increase productivity while safeguarding the ecological advantages of organic farming (Niggli, 2014).

Eco-functional intensification means to generate productivity gains by activating ecosystem services and functions. This is in most cases the result of redesigning crop rotations, natural and semi-natural habitats and consequently the entire farm. The use of biocontrol organisms and botanicals in plant and animal strengthening and disease and pest control are other examples of eco-functional intensification. They are emerging technologies and are increasingly adopted by the industry (see their strong interest in the Annual Biocontrol Industry Meeting in Basel, Switzerland (ABIM, 2015)).

As synthetic pest control agents will never be an option for organic agriculture (see Table 3), well selected techniques which mimic natural mechanisms might be helpful for organic horticultural production. So far, organic regulations have a rather conservative approach to such innovations pursued, for example, by the interdisciplinary research field of bionics, where experts in the fields of biology, technology, engineering and design work together, identifying possible applications for solutions that nature has created in the course of evolution (Von Gleich et al., 2007). It would be worthwhile for organic farmers to look into this kind of innovation as well, especially when critical bottlenecks of organic farming still require borderline interventions like Copper, Sulphur or mineral oil sprays or chemical veterinary medications.

Thirdly, technological innovation has always played a role in the development of organic agriculture and will do so also in the future. For some technologies such as mechanical and thermal weeding, organic agriculture has been a leader of innovation (Niggli, 2007b). Novel developments in precision agriculture will become more prominent on organic farms in general but especially on broad-acre farms. A good example is a combination of contour farming with strip cropping which enables farmers to establish crop rotations in time and in space so that crops can profit from effects from the precedent crops as well as from adjacent ones. Precision farming might also play a role for the application of sprays compliant with organic regulations, for the application and dispersion of organic fertilizers and for the precise control of mechanical and thermal weeding devices.

Plant and animal breeding techniques such as genome-wide selection, an advanced application of marker-assisted breeding, have potential to accelerate the breeding progress for quantitative trait loci, which are often important for organic agriculture (Desta \& Ortiz, 2014). They might be both contradicting and synergistic with the more holistic approach of organic breeding where phenotypic selection plays an important role (the "breeder's eye"). Some scientists even regard the latest molecular breeding techniques (precision breeding or genome editing) as compatible with the principles of IFOAM (Andersen et al., 2015).

Many of the examples given for future innovation on organic farms demonstrate the necessity of a custodian platform enabling a critical discourse on progress which is in compliance with the organic principles and on the modernization pathways organic agriculture will adopt. Stronger than in the past, innovation will become an area of tension between a bottom-up, farmer-driven and top-down, science-driven approach (Levidow, 2011; Marsden, 2013).

Future research requires explicit interdisciplinary cooperation and an improved dialogue with farmers and an involvement of these actors as co-researchers and as co-facilitators of knowledge. On the one hand, this integration of farmers increases the cost efficiency of research and the results are multiplied effectively among fellow farmers. Interdisciplinary and transdisciplinary research on a high scientific level will lead to the next stage of organic agriculture development and is indispensable.

Fourthly, a shift towards impacts and outcomes will be needed in order to increase both transparency and credibility for policy makers, environmentalists and consumers. Organic agriculture regulations focus with their minimum requirements on inputs and on general bans of technologies (see Table 3). A comprehensive set of indicators such as the Sustainability Assessment of Food and Agriculture Systems (SAFA) guidelines by FAO or the Best Practice Guideline for Agriculture and Value Chains of the Sustainable Organic Agriculture Action Network (SOAAN) of IFOAM will increase the sustainability of organic agriculture and help to identify unsuitable developments of organic farm practices (FAO, 2015; SOAAN, 2013).

Therefore, "Organic Agriculture 3.0" also means constantly striving for best practice. This can be learnt from 
agroecology as well.

\section{References}

ABIM. (2015). Annual Biocontrol Industry Meeting. Retrieved from http://www.abim.ch/home-abim.html

Altieri, M. A. (1995). Agroecology: The science of sustainable agriculture (2nd ed.) Boulder, CO: Westview Press.

Altieri, M., \& Nicholls, C. (2005). Agroecology and the search for a truly sustainable agriculture. 1st Edition. Berkeley, CA, University of California. Retrieved from http://www.agroeco.org/doc/agroecology-engl-PNUMA.pdf

Altieri, M. A., Nicholls, C., Henao, A., \& Lana, M. A. (2015). Agroecology and the design of climate change-resilient farming systems. Agron. Sustain. Dev. http://dx.doi.org/10.1007/s13593-015-0285-2

Andersen, M. M., Landes, X., Xiang, W., Anyshchenko, A., Falhof, J., Østerberg, J. P., ... Palmgren, M. G. (2015). Feasibility of new breeding techniques for organic farming. Trends in Plant Science, 20(7), 426-434. http://dx.doi.org/10.1016/j.tplants.2015.04.011

Arbenz, M. (2015). Moving Toward Organic 3.0. In H. Willer \& J. Lernoud (Eds.) The World of Organic Agriculture. Statistics and Emerging Trends 2015 (pp. 272-274). FIBL-IFOAM Report, Frick and Bonn.

Beus, C., \& Dunlap, R. (1991). Measuring adherence to alternative vs. conventional agricultural paradigm: A proposed scale. Rural Sociology, 56(3), 432-60.

BLW. (2015). Direct payments. Website of Bundesamt für Landwirtschaft. Retrieved from http://www.blw.admin.ch/themen/00006/index.html?lang=en

Braun, S., Rahmann, G., \& Strotdrees, S. L. (2010). R-Evolution des Ökolandbaus!? Ökolandbau 3.0. Johann-Heinrich von Thünen-Institut. Retrieved from http://literatur.ti.bund.de/digbib_extern/dn054755.pdf

COSA. (2013). The COSA Measuring Sustainability Report: Coffee and Cocoa in 12 Countries (p. 100). Philadelphia, PA: The Committee on Sustainability Assessment.

Council of the European Communities. (1992). Council Regulation (EEC) No 2078/92 of 30 June 1992 on agricultural production methods compatible with the requirements of the protection of the environment and the maintenance of the countryside. In: Official Journal L 215, 30/07/1992 P. 0085 - 0090. Retrieved from http://eur-lex.europa.eu/legal-content/DE/TXT/?uri=uriserv:OJ.L_.1992.215.01.0085.01.ENG

De Schutter, O. (2014). Report of the Special Rapporteur on the right to food, Olivier De Schutter. Final report: The transformative potential of the right to food. Human Rights Council of the United Nations. Retrieved from http://www.srfood.org/images/stories/pdf/officialreports/20140310_finalreport_en.pdf

Desta, Z. A., \& Ortiz, R. (2014). Genomic selection: genome-wide prediction in plant improvement. Trends Plant Sci., 19(9), 592-601. http://dx.doi.org/10.1016/j.tplants.2014.05.006

DFG memorandum. (2005). Future Perspectives of Agricultural Science and Research. Deutsche Forschungsgemeinschaft (p. 84). Wiley-VCH-Verlag.

Disler, M., Schmid, K., Ivemeyer, S., Hamburger, M., \& Walkenhorst, M. (2013). Traditional homemade herbal remedies used by farmers of northern Switzerland to treat skin alterations and wounds in livestock. Planta Medica, 79 -PL24. http://dx.doi.org/10.1055/s-0033-1352332

European Commission. (2013). Agriculture and Rural Development. Cap Reform basic regulation published. Website of the European Commission. Retrieved from $\mathrm{http} / / /$ ec.europa.eu/agriculture/newsroom/155_en.htm

FAO. (2015). Sustainability Assessment of Food and Agriculture Systems (SAFA). Food and Agriculture Organization of the United Nations (FAO), Rome. Retrieved from http://www.fao.org/nr/sustainability/sustainability-assessments-safa/en

Geier, B. (2007). IFOAM and the History of the International Organic Movement. In W. Lockeretz (Ed.), Organic Farming: an international history (pp. 175-186). CAB International. Wallingford, UK. http://dx.doi.org/10.1079/9780851998336.0175

Hine R., Pretty J., \& Twarog, S. (2008). Organic agriculture and food security in Africa. (UNCTAD/DITC/TED/2007/15). United Nations, Geneva and New York.

Huber, B., Schmid, O., \& Napo-Bitantem, G. (2015). Standards and Regulations. In H. Willer \& J. Lernoud,(Eds.), The World of Organic Agriculture. Statistics and Emerging Trends (pp. 126-133). FIBL-IFOAM Report, Research Institute of Organic Agriculture (FiBL), Frick and IFOAM Organics 
International, Bonn.

IFOAM. (2015). Principles of organic agriculture. Health, Ecology, Fairness and Care. Website of IFOAM Organics International. Retrieved from http://www.ifoam.bio/en/organic-landmarks/principles-organic-agriculture

ITF (2008). EquiTool. Guide for Assessing Equivalence of Organic Standards and Technical Regulations. International Task Force on Harmonization and Equivalence in Organic Agriculture. United Nations Conference on Trade and Development (UNCTAD), Geneva, Food and Agriculture Organization (FAO), Rome, and International Federation of Organic Agriculture Movements (IFOAM), Bonn. Retrieved from http://r0.unctad.org/trade_env/itf-organic/meetings/itf8/ITF_EquiTool_finaldraft_080915db2.pdf

Kirchner, C. (2015). Overview of Participatory Guarantee Systems in 2014. In H. Willer \& J. Lernoud (Eds.), The World of Organic Agriculture. Statistics and Emerging Trends (pp. 134-136). FiBL-IFOAM Report. Research Institute of Organic Agriculture (FiBL), Frick and IFOAM Organics International, Bonn.

Koohafkan, P., Altieri, M. A., \& Gimenez, E. H. (2011). Green agriculture: foundations for biodiverse, resilient and productive agricultural systems. Int J Agric Sustain, 61-75.

Kuhn, S. (1970). The Structure of Scientific Revolutions, University of Chicago Press, Chicago.

Lammerts van Bueren, E. T., Struik, P. C. M., Tiemens-Hulscher, M., \& Jacobsen, E. (2003). Concepts of Intrinsic Value and Integrity of Plants in Organic Plant Breeding and Propagation. Crop Sci, 43, 1922-1929. http://dx.doi.org/10.2135/cropsci2003.1922

Lampkin, N. (1990). Organic Farming (p. 701). Farming Press.

Lange, St., Williges, U., Saxena, S., \& Willer, H. (2006). European Research in Organic Food and Farming. Reports on organisation and conduction of research programmes in 11 European countries (p. 281). The ERA-NET scheme on Coordination of European Transnational Research in Organic Food and Farming (CORE Organic). Retrieved from http://www.orgprints.org/8798/

Levidow, L. (2011). Agricultural Innovation: Sustaining What Agriculture? For What European Bio-economy? (p. 32) Final report of the project 'Co-operative Research on Environmental Problems in Europe' (CREPE). Retrieved from http://crepeweb.net

Levidow, L., Pimbert, M., \& Vanloqueren, G. (2014). Agroecological Research: Conforming—or Transforming the Dominant Agro-Food Regime? Agroecology and Sustainable Food Systems, 38(10), 127-1155. http://dx.doi.org/10.1080/21683565.2014.951459

Lockeretz, W. (2002). Strategies for organic research. Organic and conventional research: How different? In Powell et al. (Eds). UK Organic Research 2002: Proceedings of the COR Conference, 26-28th March 2002, Aberystwyth (pp. 25-31). Retrieved from http://orgprints.org/8490/1/8490.pdf

Lutzeyer, H.-J., \& Kovacs, B. (2012). A decade of EU-funded, low-input and organic agriculture research (2000-2012). European Commission (p. 284). Retrieved from http://ec.europa.eu/research/bioeconomy/pdf/189756_2011_2695_a_decade_of_eu_en.pdf

Marsden, T. (2013). From post-productivism to reflective governance. Contested transitions in securing more sustainable food futres. Journal of Rural Studies, 29, 123-143. http://dx.doi.org/10.1016/j.jrurstud.2011.10.001

Ministère de l'agriculture, de l'agroalimentaire et de la forêt. (2013). Le projet agro-écologique pour la France. http://agriculture.gouv.fr/le-projet-agro-ecologique-pour-la-france

Niggli, U. (2007a). FiBL and Organic Research in Switzerland. In W. Lockeretz (Ed.), Organic Farming: An international history (pp. 242-252). CAB International. Wallingford, UK. http://dx.doi.org/10.1079/9780851998336.0242

Niggli, U. (2007b). The Evolution of Organic Practice. In W. Lockeretz (Ed.), Organic Farming: an international history (pp. 73-92). CAB International. Wallingford, UK. http://dx.doi.org/10.1079/9780851998336.0073

Niggli, U. (2014). Sustainability of Organic Food Production: Challenges and Innovations (p. 6). Proceedings of the Nutrition Society.

Niggli, U., Slabe, A., Halberg, N., Schmid, O., \& Schlüter, M. (2008). Vision for an Organic Food and Farming Research Agenda to 2025 (p. 48). Published by IFOAM EU Group and FiBL, Brussels and Frick.

NOSB. (2013). National Organic Standards Board, GMO ad hoc Subcommittee. Discussion Document. Excluded Methods Terminology. Retrieved February 6, 2013, from http://www.ams.usda.gov/AMSv1.0/getfile?dDocName=STELPRDC5102656 
Oelofse, M. (2010). The Sustainability of Organic Farming in a Global Food Chains Perspective. The Agroecology of Organic Farming Systems (p. 135). PhD Thesis, Faculty of Life Sciences. University of Copenhagen.

Parmentier, St. (2014). Scaling-up agroecological approaches: what, why and how. Discussion paper (p. 93). Published by Oxfam-Solidarity, Belgium. Retrieved from http://futureoffood.org/pdfs/OXFAM_2014_Scaling_Up_Agroecological_Approaches.pdf

Pretty, J. N. (2008). Agricultural sustainability: concepts, principles and evidence. Philosophical Transactions of the Royal Society B, 363, 447-465. http://dx.doi.org/10.1098/rstb.2007.2163

Rützler, H., \& Reiter, W. (2014). Organic 3.0. Trend and potential analysis of the future of organics. Zukunftsinstitut Österreich. p. 64. Retrieved from https://www.biofach.de/en/press/organic-study

Schmid, O. (2007). Development of Standards for Organic Farming. In W. Lockeretz (Ed.), Organic Farming: An international history (pp. 152-174). $\mathrm{CAB}$ International. Wallingford, UK. http://dx.doi.org/10.1079/9780851998336.0152

SOAAN. (2013). Best Practice Guideline for Agriculture and Value Chains. Public Version 1.0 - December 2013. Sustainable Organic Agriculture Action Network/ IFOAM Organics International, Bonn. Retrieved from http://www.ifoam.bio/sites/default/files/best_practice_guideline_v1.0_ratified.pdf

Stinner, D. H. (2007). The Science of Organic Farming. In W. Lockeretz (Ed.), Organic Farming: an international history (pp. 40-72). CAB International. Wallingford, UK. http://dx.doi.org/10.1079/9780851998336.0040

Tittonell, P. (2014). Ecological intensification of agriculture - sustainable by nature. Current Opinion in Environmental Sustainability, 8, 53-61. http://dx.doi.org/10.1016/j.cosust.2014.08.006

Via Campesina. (2015). The website of Via Campesina. Retrieved from http://viacampesina.org/en/

Vogt, G. (2007). The origin of organic farming. In W. Lockeretz (Ed.), Organic Farming: An international history (pp. 9-29). CAB International. Wallingford, UK. http://dx.doi.org/10.1079/9780851998336.0009

Von Gleich, A., Pade, Ch., Petschow, U., \& Pissarskoi, E. (2007). Bionik. Aktuelle Trends und zukünftige Potenziale (p. 236). Universität Bremen.

Wezel, A., Bellon, S., Doré, T., Francis, C., Vallod, D., \& David, C (2009). Agroecology as a science, a movement or a practice. A review. Agron Sustain Dev, 29, 503-515. http://dx.doi.org/10.1051/agro/2009004

Wezel, A., Casagrande, M., Celette, F., Vian, J.-F., Ferrer, A., \& Peigné, J. (2014). Agroecological practices for sustainable agriculture. A review. Agron. Sustain, Dev, 34, 1-20. http://dx.doi.org/10.1007/s13593-013-0180-7

Willer, H., \& Lernoud, J. (2015). The World of Organic Agriculture. Statistics and Emerging Trends 2015 (p. 300). FIBL-IFOAM Report, Research Institute of Organic Agriculture (FiBL), Frick and IFOAM Organics International, Bonn.

Wynen, E. (1996). Research Implications of a Paradigm Shift in Agriculture: The Case of Organic Farming. Resource and Environmental Studies, no. 12. Centre for Resource and Environmental Studies, Australian National University, Canberra.

Zander, K., \& Hamm, U. (2009). Farmer Consumer Partnerships: Information search and decision making - the case of ethical values of organic products (p. 52). CORE Organic project No 1897.

Zehnder, G., Gurr, G. M., Kühne, S., Wade, M. R., Wratten, S. D., \& Wyss, E. (2007). Arthropod pest management in organic crops. Annual Review of Entomology, 52, 57-80. http://dx.doi.org/10.1146/annurev.ento.52.110405.091337

\section{Copyrights}

Copyright for this article is retained by the author(s), with first publication rights granted to the journal.

This is an open-access article distributed under the terms and conditions of the Creative Commons Attribution license (http://creativecommons.org/licenses/by/3.0/). 